\title{
Manajemen Pendidikan Berbasis Produksi
}

\author{
${ }^{1 .}$ Heni Noviarita, ${ }^{2 .}$ Arman Syahyudi, ${ }^{3 .}$ Imam Agung Wijaya \\ ${ }^{1 .}$ Pascasarjana UIN Raden Intan Lampung \\ 1. heninoviarita@ radenintan.ac.id, 2. armansyahyudi21@gmail.com, \\ 3. Imamagungwijaya23@gmail.com
}

\begin{abstract}
In this study, it will be further discussed how the production of education and the function of production in education will be discussed. The formulation of the problem in this research are; 1) how is the production system in education?; 2) what is the function of production in education. This study uses a qualitative descriptive research approach with the type of literature study. Literature research is carried out through books, magazines, journals, the internet and so on. In addition, by conducting observational studies from previous studies. The results found are; 1) that educational inputs are the basic ingredients of the educational process to produce educational outputs. Education output is classified as consumption and investment. Aspects of consumption related to joy, pleasure, social status, security (reduction of crime rates) and skilled labor; that can be obtained and enjoyed by students, families, and society as a whole. Meanwhile, the investment aspect includes educational outcomes related to increasing the productive skills of a person and society to achieve future prosperity. 2) The production function in education is the administrator's production function, the psychological production function, and the economic production function.
\end{abstract}

Keywords: Education, Production, Function.

\begin{abstract}
ABSTRAK
Dalam penelitian ini akan lebih jauh dibahas bagaimana produksi pendidikan serta fungsi produksi dalam pendidikan. Perumusan masalah dalam penelitian ini adalah; 1) bagaimana sistem produksi dalam pendidikan?; 2) bagaimana fungsi produksi dalam pendidikan. Penelitian ini menggunakan pendekatan penelitian deskriptif kualitatif jenis dengan jenis penelitian studi pustaka. Penelitian kepustakaan di lakukan melalui buku, majalah, jurnal, internet dan sebagainya. Selain itu dengan melakukan studi pengamatan dari penelitian-penelitian sebelumnya. Hasil yang ditemukan yaitu; 1) bahwa Input pendidikan merupakan bahan dasar dari proses pendidikan untuk menghasilkan output pendidikan. Output pendidikan diklasifikasikan sebagai konsumsi dan investasi. Aspek konsumsi berhubungan dengan kegembiraan, kesenangan, status sosial, keamanan (pengurangan angka kriminalitas) dan tenaga kerja terampil; yang dapat diperoleh dan dinikmati oleh siswa, keluarga, dan masyarakat secara keseluruhan. Sementara itu aspek investasi mencakup outcome pendidikan yang terkait dengan peningkatan keterampilan produktif seseorang dan masyarakat untuk mencapai kesejahteraan masa depan. 2) Fungsi produksi dalam pendidikan adalah fungsi produksi administrator, fungsi produksi psikologi, dan fungsi produksi ekonomi.
\end{abstract}

Kata kunci: Pendidikan, Produksi, Fungsi,. 


\section{PENDAHULUAN}

Pendidikan adalah faktor penting untuk mewujudkan sumber daya manusia (SDM) yang berkualitas. Pendidikan juga merupakan sarana strategis guna peningkatan mutu sumber daya manusia baik dalam pembangunan suatu bangsa maupun dalam tatanan global. Pendidikan adalah investasi jangka panjang yang akan mempengaruhi pertumbuhan ekonomi suatu bangsa (Malayu hasibuan, 2017:5). Sedangkan sumbersumber modal dan materi merupakan faktor-faktor produksi yang hanya dapat diaktifkan oleh sumber daya manusia.

Diera globalisasi ini, pendidikan sangatlah dibutuhkan bagi generasi penerus bangsa, apalagi untuk menghadapi Revolusi Industri 4.0. Maka peran serta dunia pendidikan sangatlah dibutuhkan untuk mencerdaskan generasi penerus bangsa. Dalam hal ini di cantumkan dalam pembukaan UUD RI 1945 yang berbunyi "Mencerdaskan Kehidupan Bangsa" dengan demikian ini merupakan kewajiban pemerintah untuk mewujudkan hal ini. Untuk mencapai tujuan tersebut harus melalui proses. Dari proses yang baik tersebut, akan menghasilkan sebuah produk.

Produk yang di harapkan adalah menghasilkan SDM yang berkualitas, berdaya guna dan mampu menghadapi dunia kerja. Selain SDM , hasil produksi adalah barang yang di hasilkan suatu perusahaan yang berkualitas, daya saing dan bernilai guna. Untuk mencapai hal tersebut tentunya paham dengan apa itu biaya produksi yang dibutuhkan oleh suatu perusahaan. Dari latar belakang tersebut, peneliti ingin memaparkan tentang produksi dalam bidang pendidikan serta fungsi produksi dalam bidang pendidikan.

Dalam upaya membentuk sumber daya manusia yang produktif, maka sistem pendidikan, struktur kurikulum, serta jenis pendidikan diatur kembali selanjutnya biaya pendidikan ditingkatkan, sesuai dengan prinsip produksi dalam dunia pendidikan dapat digunakan untuk mendapatkan meningkatkan kualitas dan juga mendasari penentuan maju mundurnya suatu sekolah, perilaku konsumen ditentukan oleh kualitas pendidikan yang dimiliki. Dalam hal ini keputusan yang diambil oleh seorang konsumen dalam menentukan pilihan atas alternatif tersebut. Produsen mencoba memaksimumkan produksi yang bisa dicapai dengan mengelola biaya pendidikan dengan maksimum sehingga biaya produksi tidak mengalami kekurangan dana.

An Naba : Jurnal Pemikiran Dan Penelitian Pendidikan Islam 


\section{METODE PENELITIAN}

Penelitian ini menggunakan pendekatan kualitatif yaitu menerapkan proses penelitian dengan tujuan untuk mendapatkan result dan value data yang deskriptif. Data yang ditemukan akan dikumpulkan baik berupa hasil ucapan, tulisan dan hal-hal serupa terkait lainnya yang memiliki kontinuitas agar dapat diteliti dan diamati secara berkelanjutan. Dengan metode ini, diharapkan agar hasil dari penelitian ini dapat memberikan data dan analisis yang bisa merepresentasikan tema penelitian.

Penelitian kualitatif dapat dikatakan bentuk penelitian yang menghasilkan karya ilmiah yang menggunakan data uraian deskriptif yang berupa tertulis atau perkataan orang yang sebagai pelaku langsung, baik berupa kelompok atau objek sendiri yang di khususkan (Arikunto, 2010). Penelitian dengan menggunakan gaya pendekatan deskriptif kualitatif yaitu penelitian yang berusaha dalam mengupayakan dalam memberikan kejelasan berupa data lapangan dan tidak ada hubunganya dengan data yang berbasis angka. Tetapi penelitian yang bersifat keperpustakaan adalah serangkaian usaha sadar yang berkesinambungan dengan pengumpulan data pustaka, membaca dari beberapa sumber dan mencatat hal yang penting dan dikelolah menjadi bahan yang utuh dalam penelitian (Creswell, 2018: 253).

\section{HASIL DAN PEMBAHASAN}

\section{Pengertian Produksi}

Produksi dalam istilah konvensional adalah sebagai penciptaan kemampuan barang atau jasa untuk memenuhi kebutuhan manusia. Menurut definisi ini produksi mencakup pengertian yang sangat luas sekali produksi meliputi semua aktivitas dan tidak hanya mencangkup pembuatan barang-barang yang dapat dilihat (Sudarman, 2004:103).

Produksi adalah proses mencari, mengalokasikan dan mengolah sumber daya menjadi output dalam rangka meningkatkan mashlahah bagi manusia. Oleh karena itu, produksi juga mencakup aspek tujuan kegiatan menghasilkan output serta karakterkarakter yang melekat pada proses dan hasilnya (P3EI, 2013).

Produksi dalam pandangan islam memiliki arti sebagai bentuk usaha keras dalam pengembangan faktor-faktor sumber yang diperbolehkan dengan tujuan kesejahteraan 
masyarakat menompang eksistensi serta ketinggian derajat manusia. Produksi dalam persepektif islam adalah sebagai usaha manusia untuk memperbaiki tidak hanya kondisi fisik materialnya, tetapi juga moralitas, sebagai sarana untuk mencapai tujuan hidup sebagaimana digariskan dalam agama islam, yaitu kebahagiaan dunia akhirat.

\section{Teori Produksi}

Teori produksi adalah teori yang menerangkan sifat hubungan antara tingkat produksi yang akan dicapai dengan jumlah faktor- faktor produksi yang digunakan. Konsep utama yang dikenal dalam teori ini adalah memproduksi output semaksimal mungkin dengan input tertentu dengan biaya produksi seminimal mungkin.

Dalam teori produksi, dikenal beberapa cara yang dapat digunakan untuk meningkatkan produksinya, yaitu:

a. Ekstensifikasi Merupakan peningkatan produktivitas dengan cara menambahkan sejumlah faktor produksi yang digunakan.

b. Intensifikasi Dilakukan dengan cara memaksimalkan kapasitas faktor produksi yang telah ada.

c. Rasionalisasi Merupakan peningkatan produktivitas yang dilakukan dengan mengeluarkan kebijakan yang akan meningkatkan efisiensi produksi, terdiri dari:

1) Mekanisme merupakan menjadi sifat padat karya menjadi padat modal dengan menggunakan mesin-mesin modern.

2) Spesialisasi melakukan pembagian kerja sehingga satu orang bertanggung jawab pada satu jenis pekerjaan saja.

3) Standarisasi membuat standar tertentu terhadap bentuk, ukuran, bobot, dan detail lainnya dari suatu produk (Rozalinda, 2014:115).

\section{Jenis-Jenis Teori Produksi}

a. Teori Produksi dengan Satu Faktor Berubah

Teori produksi yang sederhana menggambarkan tentang hubungan diantara tingkat produksi suatu barang dengan jumlah tenaga kerja yang digunakan untuk menghasilkan berbagai tingkat produksi barang tersebut. Dalam analisis tersebut dimisalkan bahwa faktor-faktor produksi lainnya adalah tetap jumlahnya, yaitu modal dan tanah jumlahnya 
dianggap tidak mengalami perubahan, teknologi dianggap tidak mengalami perubahan. Satu-satunya faktor produksi yang dapat diubah jumlahnya adalah tenaga kerja.

b. Teori Produksi Dengan Dua Faktor Berubah

Terdapat dua jenis faktor produksi yang dapat diubah jumlahnya, contoh yang dapat diubah adalah tenaga kerja dan modal, di contohkan pula bahwa kedua faktor produksi yang dapat berubah ini dapat dipertukar-tukarkan penggunaannya; yaitu tenaga kerja dapat menggantikan modal atau sebaliknya (Sadono, 2014).

c. Teori Biaya

Biaya atau ongkos produksi adalah semua pengeluaran yang dilakukan oleh perusahaan untuk memperoleh faktor produksi dan bahan mentah yang akan digunakan untuk produksi. Ada tiga fenomena yang biasanya muncul akibat penambahan faktor produksi yang berkaitan dengan output produksi yaitu:

1) Skala hasil yang tetap (costan retrun to scale) yaitu kenaikan output memiliki proporsi yang sama dengan penambahan input.

2) Skala hasil yang meningkat (increasing return to scale) yaitu kenaikan output memiliki proporsi yang lebih besar dibandingkan dengan penambahan input.

3) Skala hasil yang menurun (decreasing return to scale) yaitu kenaikan output memiliki proporsi yang lebih kecil dibandingkan dengan penambahan input.

Kegiatan produksi terdiri dari 3 komponen yaitu input, diproses dan ouput, dimana output diproses menjadi output. Bentuk hubungan antara input dan output tersebut digambarkan dalam satu fungsi yang dinamakan fungsi produksi.

\section{Sistem Produksi Lembaga Pendidikan}

Lembaga pendidikan yang dimaksudkan di sini adalah lembaga formal dalam bentuk sekolah. Menurut Becker (1993), sekolah dapat didefinisikan sebagai "institusi yang mengkhususkan pada produksi pelatihan, untuk membedakan dengan perusahaan yang menawarkan pelatihan dalam rangka produksi barang”. Sementara itu Cohn menyatakan bahwa "Fungsi produksi pendidikan pada prinsipnya sama dengan fungsi produksi lain" (1979). Dalam hal ini seperti hubungan matematik yang menggambarkan bagaimana sumberdaya (inputs) dapat diolah menjadi keluaran (outputs atau outcomes), atau seperti dikemukakan Hanushek (dalam Psacharopoulos, 1987) bahwa "pro- duction function relate the various educational inputs to educational outputs". Dengan demikian proses

An Naba : Jurnal Pemikiran Dan Penelitian Pendidikan Islam 
pengolahan inputs pendidikan menjadi outputs atau outcomes merupakan unsur penting untuk menggambarkan fungsi produksi pendidikan secara lengkap.

Cohn (1979) menjelaskan bahwa input pendidikan meliputi karakteristik siswa, faktor-faktor sekolah (school factors) dan pengaruh lain dari lingkungan masyarakat (nonschool factors). Input sekolah mencakup unsur sumberdaya manusia dan fisik. Sumberdaya manusia antara lain: guru, kepala sekolah, pegawai administrasi dan staf pendukung lain, konselor, laboran, dan pustakawan. Karakteristik sumberdaya manusia tersebut —seperti pendidikan, pengalaman, motivasi, beban tugas dan insentif yang diberikan — dapat mempengaruhi proses pendidikan dan selanjutnya berdampak pada hasil pendidikan. Adapun unsur fisik meliputi antara lain: karakteristik bangunan, jumlah dan kualitas peralatan pendidikan, buku, dan peralatan pendukung pembelajaran lainnya.

Sementara itu input non-sekolah mencakup antara lain: teman sejawat, status sosial ekonomi orang tua (pendidikan, pendapatan, kepemilikan buku di rumah), suku, ukuran keluarga, karakteristik lingkungan siswa (seperti tingkat urbanisasi, tingkat kemakmuran dan standar perumahan, komposisi penduduk, rata-rata pencapaian pendidikan orang dewasa, dan rata-rata pendapatan dan kesejahteraan). Faktor-faktor ini dapat secara langsung maupun tidak langsung mempengaruhi pretasi belajar siswa.

Input pendidikan merupakan bahan dasar dari proses pendidikan untuk menghasilkan output pendidikan. Menurut Schultz (dalam Cohn, 1979), output pendidikan dapat diklasifikasikan menjadi dua kategori, yaitu sebagai konsumsi dan investasi. Dalam konteks ini Vaizey (1962) menganalogikan konsumsi seperti membeli roti atau susu, sebagai sesuatu yang langsung dapat dinikmati, sementara investasi, seperti membeli mesin atau membangun toko, merupakan bentuk pengeluaran saat ini untuk mendapatkan keuntungan dalam jangka panjang. Untuk itu "investment is restricted to a single period and returns to all remaining periods" (Becker, 1993). Dengan demikian konsumsi dapat diartikan sebagai bentuk pengeluaran yang dapat langsung atau segera dinikmati hasilnya; dan investasi merupakan bentuk pengeluaran saat ini yang baru dapat dinikmati hasilnya setelah jangka waktu tertentu, secara berkelanjutan dalam jangka panjang.

Dalam pendidikan, aspek konsumsi berhubungan dengan kegembiraan, kesenangan, status sosial, keamanan (pengurangan angka kriminalitas) dan tenaga kerja terampil; yang dapat diperoleh dan dinikmati oleh siswa, keluarga, dan masyarakat secara keseluruhan. 
Sementara itu aspek investasi mencakup outcome pendidikan yang terkait dengan peningkatan keterampilan produktif seseorang dan masyarakat untuk mencapai kesejahteraan masa depan. Contoh output pendidikan yang bersifat investasi ini antara lain: keterampilan dasar matematik dan verbal, keterampilan vokasional, kreativitas, kebiasaan hidup sehat, dan penanaman nilai-nilai sosial dan moral yang mengarah kepada pengembangan sikap kewarga-negaraan, atau pengembangan sikap positip terhadap diri sendiri, keluarga, teman dan masyarakat.

Dengan demikian dapat disimpulkan bahwa hasil-hasil pendidikan dapat dinikmati oleh individu peserta didik, keluarganya, masyarakat dan negara pada umumnya. Keuntungan tersebut baik berupa konsumsi (dapat dinikmati secara langsung dalam jangka pendek) maupun investasi (yang dapat dinikmati hasilnya setelah dalam jangka waktu yang relatif lama).

Bagaimanapun hasil-hasil pendidikan di atas, sangat tergantung pada cara pemrosesan in- puts yang tersedia. Menurut Kidwell dan O'Brien (dalam Johnson dan Rush, 1995), suatu proses adalah “....a series of linked activities in which an input is transformed into an output and a tangible product is delivered to an external customer". Jadi proses dapat diartikan sebagai serangkaian kegiatan yang saling terkait dimana suatu input diolah menjadi suatu output, dan suatu produk nyata disampaikan kepada pelanggan eksternal. Suatu proses dimulai dengan mengidentifikasi keluaran organisasi dan identifikasi pelanggan luar yang akan menggunakan keluaran tersebut. Dengan identifikasi keluaran dan kebutuhan pelanggan tersebut maka efektivitas dan efisiensi dari suatu proses dapat dinilai secara jelas (Udik Budi Wibowo, 2008).

\section{Fungsi Produksi dalam Pendidikan}

Fungsi produksi dalam pendidikan, yang meliputi: fungsi produksi administrator, fungsi produksi psikologi, dan fungsi produksi ekonomi (Made Pidarta, 2007:254) yang dipandang secara input maupun output dari masing masing fungsi tersebut:

a) Fungsi Produksi Administrator adalah segala sesuatu yang menjadi bahan dan proses pendidikan. Input dalam produksi administrator adalah sarana dan prasarana (Sarpras), media belajar, alat peraga, buku, film, kertas, dan waktu guru serta staf dalam bekerja untuk melayani peserta didik. Fungsi Produksi Admnistrator ini termasuk input kepada peserta didik.

An Naba : Jurnal Pemikiran Dan Penelitian Pendidikan Islam 
b) Fungsi Produksi Psikologi adalah berbagai bentuk layanan dalam memproses peserta didik. Lazimnya dalam hal ini dihitung lewat sistem kredit semester (SKS). Ouput pada fungsi produksi psikologi ini adalah peningkatan kepribadian, pengerahan dan pembentukan sikap, penguatan kemauan, peningkatan estetika, penambahan IPTEK, penajaman pikiran, serta meningkatkan keterampilan. Fungsi Produksi Psikologi ini termasuk ouput kepada peseta didik.

c) Fungsi Produksi Ekonomi adalah diperhitungkan dengan mecari selisih antara input dan ouput. Hasilnya menjadi parameter akan keberhasilkan lembaga pendidikan. Maksudnya adalah Fungsi Produksi Administrator dan Fungsi Produksi Psikologi dihutung menjadi satu dan akan menimbulkan angka untuk dapat memenuhi kebutuhan input dan ouput serta dapat memberlangsungkan pendidikan dengan baik sesui dengan tujuan dari pendidikan nasional.

Pendidikan Nasional merupakan pendidikan yang berakar pada kebudayaan bangsa Indonesia dan yang berdasarkan pada pancasila serta Undang-Undang Dasar 1945. Untuk mencapai pendidikan nasional juga terdapat sistem yang mendukung yaitu sistem pendidikan nasional yang berarti keseluruhan terpadu dari semua satuan dan kegiatan pendidikan yang berkaitan satu dengan lainnya (UUD, 2003).

\section{KESIMPULAN}

Input merupakan bahan dan langkah dasar dalam sebuah proses pendidikan untuk menghasilkan sebuah output. Produksi dalam dunia pendidikan dikatakan sebagai output dari proses pendidikan. Baik atau tidaknya output sebuah pendidikan, sangat bergantung pada proses input yang dilakukan.

Hasil-hasil pendidikan dapat dinikmati oleh individu peserta didik, keluarga, masyarakat dan negara pada umumnya. Keuntungan tersebut baik berupa konsumsi (dapat dinikmati secara langsung dalam jangka pendek) maupun investasi (yang dapat dinikmati hasilnya setelah dalam jangka waktu yang relatif lama). Bagaimanapun hasil-hasil pendidikan di atas, sangat tergantung pada cara pemrosesan input yang tersedia.

\section{DAFTAR PUSTAKA}

Arikunto, Suharismi.(2010) Research Design, Pendekatan Metode Kualitatif, Al Fabet, Bandung. 
Ari Sudarman, Teori Ekonomi Mikro, (Yogyakarta: BPFE Yogyakarta, 2004), h. 103.

Becker, Gary Stanley. (1993). Human Capital : a theoretical and empirical analysis, with special reference to education 3rd edition. London : The University of Chicago Press, Ltd.

Pidarta, Made, Landasan Kependidikan (Stimulus Ilmu Pendidikan Bercorak Indonesia). (Jakarta : PT. Rineka Cipta, 2007), h. 254

Pusat Pengkajian dan Pengembangan Ekonomi Islam (P3EI), Ekonomi Islam, (Jakarta: Rajawali, 2013), h. 230-231.

Rozalinda, Ekonomi Islam Teori dan Aplikasinya Pada Aktivitas Ekonomi, (Jakarta: PT Raja Grafindo Persada, 2014), h. 115

Sadono Sukirno, Mikroekonomi Teori Pengantar Edisi Ketiga, (Jakarta: PT Raja Grafindo Persada, 2013), h. 195

Sukirno, S. (2000). Pengantar Teori Mikroekonomi (Edisi Kedua). Jakarta: PT. Raja Grafindo Persada.

Sumarsono, S. (2003). Ekonomi Manajemen Sumberdaya Manusia dan Ketenagakerjaan. Yogyakarta: Graha Ilmu.

Sutisna, O. (1989). Administrasi Pendidikan: Dasar Teoritis untuk Praktek Profesional. Bandung: Angkasa.

Udik Budi Wibowo, "Output Lembaga Pendidikan Dalam Perspektif Ekonomi Pendidikan”, Jurnal Manajemen Pendidikan, no. 02/Th IV/Oktober/2008, Hal. 21-22. Undang-Undang Republik Indonesia Nomor 20 Tahun 2003, Tentang Sistem Pendidikan Nasional

W. Creswwell, Jhon. (2018) Research Design, Pendekatan Metode Kualitatif, Pustaka Belajar, Yogyakarta. h. 253-254. 